\title{
DETECTION OF LEGIONELLA PNEUMOPHILA IN WATER AND BIOFILM SAMPLES BY CULTURE AND MOLECULAR METHODS FROM MAN-MADE SYSTEMS IN SÃO PAULO - BRAZIL
}

\author{
Fábio R. S. Carvalho; Annette S. Foronda; Vivian H. Pellizari*
}

Laboratório de Microbiologia Ambiental, Departamento de Microbiologia, Instituto de Ciências Biomédicas, Universidade de São Paulo, São Paulo, SP, Brasil.

Submitted: January 09, 2007; Returned to authors for corrections: March 30, 2007; Approved: September $20,2007$.

\begin{abstract}
Legionella pneumophila is a pathogenic bacteria associated to aquatic habitat of natural and artificial environments. Clinical cases of legionellosis have been reported in Brazil but there is a lack of information about the incidence and concentration of this bacterium in environmental sources. Thus, the present study was designed to evaluate the occurrence of legionellae in São Paulo city, Brazil, using different methods of detection and identification. Sixty-seven water and biofilm samples from natural reservoirs and man-made systems were collected and analyzed for the presence of Legionella spp by culturing onto a selective medium, coculture in axenic free-living amoebae and direct fluorescent antibody (DFA) assay. Results showed that freshwater of reservoirs did not contain legionellae, Legionella pneumophila was isolated from man-made systems, with predominance of Legionella pneumophila serogroup 1 strains. Although there was no statistical difference among the proposed detection methods, the plate culture method yielded a higher number of L. pneumophila positive samples, followed by amoebic coculture procedure and direct fluorescent antibody assay. Results of PCR and sequencing reactions revealed that application of macrophage infectivity potentiator gene as a molecular marker was an important tool for the identification of environmental isolates of $L$. pneumophila. The agreement among the three detection methods-when all methods yielded similar results- and the prevalence of a single Legionella species in the sampled man-made systems could suggest that the occurrence of this bacterium had been influenced by the higher concentration of metallic ions dissociated in water of those systems than in natural reservoirs. Thus, the results of this study revealed that the water of man-made systems in Sao Paulo may serve as a reservoir for L. pneumophila and other microorganism, including free-living protozoans.
\end{abstract}

Key words: Legionella pneumophila, free-living amoebae, man-made systems

\section{INTRODUCTION}

The genus Legionella comprises 70 distinct serogroups from 48 species (16) and new species are frequently described $(31,38,39)$. Legionella pneumophila is the etiological agent of the majority of cases of legionellosis, and the majority of Legionnaires' disease cases have been attributed to $L$. pneumophila serogroup 1 (45). In addition, at least 20 other species of Legionella have been associated with human infections (16). Legionella bacteria do exist as free-living planktonic forms in the environment (36), intracellular parasites of protozoans (3), and/ or inhabitants of mixed-community biofilms (29).Thus, the diversity of types and the ubiquitous occurrence of legionellae in water environments or moist soil make it difficult to identify epidemic strains, and outbreaks of legionellosis have been associated mainly with contamination of man-made aquatic environments $(2,16)$.

The metropolitan region of Sao Paulo State is constituted by Sao Paulo city and several other smaller cities around it. These cities are supplied by different water reservoirs where the presence of Legionella species is unknown, although the isolation of Legionella from man-made systems in São Paulo

*Corresponding Author. Mailing address: USP - ICB II - Dep. de Microbiologia - Lab. de Microbiologia Ambiental 148 - Av. Prof. Lineu Prestes, 1374

- Cidade Universitária 05508-900 - São Paulo, SP - Brasil. Tel.: (11) 3091-7205 ou (11) 3091-7354. E-mail: vivianp@usp.br 
has been described $(35,41)$. The isolation of $L$. pneumophila in Brazil was first described by Pereira Gomes et al. (42). Levin et $a l$. (35) reported the isolation of $L$. anisa from shower water and L. pneumophila $\mathrm{sg} 1$ from condensed water of the air conditioning system in a hospital building located downtown Sao Paulo city. Pellizari and Martins (41) demonstrated the presence of Legionella spp in different environmental samples from Sao Paulo city. In that study, the presence of Legionella pneumophila was detected in the boiler of a hospital. Moreover, Chedid et al. (9) described the occurrence of communityacquired pneumonia in three patients hospitalized in a southern Brazilian general university hospital. In this case L. pneumophila was detected by seroconversion and positive urinary antigen tests in two patients while the third patient presented negative serology but strongly positive urinary test.

The classical method for detection of Legionella species involves direct culture of bacteria on artificial laboratory media (18). Isolation of Legionella spp is based on streaking of clinical and environmental samples onto a buffered charcoal yeast extract agar base enriched with $\alpha$-ketoglutarate (BCYE- $\alpha$ ), supplemented with ferric iron and L-cysteine (13), while identification of the strains is mostly done by serological methods (23). Moreover, amoebic coculture procedure has been proposed in order to promote the intracellular multiplication of legionellae in vitro, and the application of natural interaction between amoebae and legionellae have been successful when conventional plate culture method has failed $(15,46)$. Recently, the polymerase chain reaction (PCR) and nucleic acid probe detection methods have been introduced, and several molecular techniques have been either developed or adapted from earlier methods for environmental monitoring (33). Genetic markers have been proposed to identify Legionella strains to the species level, including 16S ribosomal RNA, macrophage infectivity potentiator (mip), defect organelle trafficking (dotA), RNA polymerase $\beta$-subunit (rpoB) genes or $23 \mathrm{~S}-5 \mathrm{~S}$ ribosomal intergenic spacer region (23S-5S ISR) $(20,21,27,28,43)$. Other techniques have been proposed as alternatives to PCR and growth procedures to identify Legionella species, including direct fluorescent antibody (DFA) staining and latex agglutination (5). The present study aimed to compare the results obtained using the standard culture procedure, the direct fluorescent antibody (DFA) assay and the amoebic coculture procedure, in order to establish which one is the best method for the isolation and identification of Legionella spp from environmental samples. The mip gene was applied as a genetic marker to confirm the presence of potentially virulent Legionella strains.

\section{MATERIALS AND METHODS}

Sixty-seven water and biofilm samples were tested by direct fluorescent antibody assay (DFA), plate culture on a selective medium and amoebic coculture procedure. Environmental isolates obtained by culture and amoebic coculture procedures were compared by PCR amplification and sequencing of the mip gene.

\section{Sample collection and concentration}

Environmental samples (water and biofilm) were taken from the water sources indicated in Table 1, between March 2003 and January 2005. Each superficial water sample, which consisted of 1 liter portion, was collected in sterile polypropylene containers (Nalgene Co., Rochester, NY, USA) containing $0.1 \mathrm{M}$ sodium thiosulfate to neutralize residual free chlorine in the samples. Water and biofilm samples from the dental units were collected from dental water-lines supplying water to air-water syringes, high-speed handpieces and scalers. All samples were transported to the laboratory and kept at 4 to $8^{\circ} \mathrm{C}$ until analysis. Water samples were concentrated by filtration through $0.45 \mu \mathrm{m}$ pore size polycarbonate membranes (type HTTP, Millipore, Ireland). The intact membranes were asseptically removed, placed into sterile $50 \mathrm{~mL}$ screw-capped tubes (Corning Inc., Corning, NY, USA) and re-suspended in 10 $\mathrm{mL}$ of the original water samples. Each concentrated water sample was sonicated for five min to dislodge bacterial cells from the membranes using a model T7 ultrasonic bath (Thorton, São Paulo, Brazil). The cell suspension was placed in a $50^{\circ} \mathrm{C}$ water bath during $30 \mathrm{~min}$. The heat treatment of concentrated water samples was used as a selective method to reduce the numbers of non-Legionella bacteria as previously described (5). These represented the prepared samples. Negative controls were done in parallel with non-contaminated environmental water and biofilm samples. All experimental samples were processed in duplicates.

\section{Immunofluorescence techniques}

The prepared samples were stained by direct fluorescent antibody (DFA) according to the manufacturer's instructions: $10 \mu \mathrm{L}$ of each prepared samples were transferred to a twelvewell glass slide (Perfecta, São Paulo, Brazil), air-dried and heat fixed. To each well a $10 \mu \mathrm{L}$ portion of one of two fluorescein isothiocyante-labeled Legionella antibodies conjugates (mTech Alpharetta, Ga., USA) was added. The first polyclonal antibody was directed against $L$. pneumophila serogroups 1 through 14 . The second polyclonal antibody was speciesspecific and used to identify L. bozemanii serogroups 1 and 2 , L. dumoffii, L. gormanii, L. micdadei, L. longbeachae serogroups 1 and 2, L. jordanis, L. oakridgensis, L. wadsworthii, L. feeleii serogroups 1 and 2, L. sainthelensi, $L$. anisa, $L$. steigerwaltii, L. parisiensis, L. spiritensis, L. hackeliae serogroups 1 and 2, L. macceachernii, L. jamestowniensis, $L$. cherrii, L. rubrilucens, and L. erythra. The slides were examined using a Carl Zeiss fluorescence microscope under a dark field with 1000X objective lenses. Only strongly fluorescent, typical rod-shaped organisms were reported as DFA positive. 


\section{Plate culture method and presumptive tests}

Aliquots of $100 \mu \mathrm{L}$ of prepared samples were spread on duplicate plates of aBCYE selective medium Agar (Difco Laboratories, Detroit, Mich., USA) added of L-cysteine (0.44 $\left.\mathrm{mg} \mathrm{mL}^{-1}\right)$, ferric pyrophosphate $\left(0.250 \mathrm{mg} \mathrm{mL}^{-1}\right)$, glycine $(3.0 \mathrm{~g}$ $\left.\mathrm{L}^{-1}\right)$, vancomycin $\left(0.0025 \mathrm{mg} \mathrm{mL}^{-1}\right)$ and polymyxin $\mathrm{B}(0.006 \mathrm{mg}$ $\mathrm{mL}^{-1}$ ), named $\alpha B C Y E-G V P$ selective agar medium (50). Plates were incubated at $37^{\circ} \mathrm{C}$ in a humidified atmosphere without $\mathrm{CO}_{2}$ during 5 days. Colonies with the typical "ground glass" appearance of Legionella were subcultured on two non-selective media, sheep-blood agar and $\alpha B C Y E$ agar without L-cysteine. Colonies that grew on $\alpha B C Y E-G V P$ but not on non-selective media were considered putative Legionella strains, and were Gram stained and subcultured on a selective medium. The identification of putative Legionella strains as Legionella pneumophila or non-Legionella pneumophila was carried out using Legionella specific latex reagents (Oxoid, Hampshire, England) and direct immunofluorescence assay with polyclonal rabbit sera (m-Tech Alpharetta, Ga., USA).

\section{Amoebic coculture procedure}

Acanthamoeba castellanii (strain ATCC 30011, Manassas, VA, USA) was grown in a $25 \mathrm{~cm}^{2}$ cell culture flask (Costar, Cambridge, Mass., USA) containing Neff's amoebae medium (120.0 mg NaCl, $3.0 \mathrm{mg} \mathrm{MgCl} 2.6 \mathrm{H}_{2} \mathrm{O}, 3.0 \mathrm{mg} \mathrm{CaCl}, 3.0 \mathrm{mg} \mathrm{FeSO}_{4}$, $142.0 \mathrm{mg} \mathrm{Na} \mathrm{HPO}_{4}, 136.0 \mathrm{mg} \mathrm{KH} \mathrm{KH}_{4}, 10.0 \mathrm{~g}$ Proteose Peptone, $18.0 \mathrm{~g}$ glucose, $1.0 \mathrm{~L}$ distilled water, $\mathrm{pH}$ 6.8). Amoebae were collected for coculture procedure by vigorous agitation of the media when cells had formed a confluent layer on the bottom of the flask $\left(1.0 \times 10^{6}\right.$ cells $\left.\mathrm{mL}^{-1}\right)$. Amoebae were harvested and pelleted by centrifugation at $1,000 \mathrm{x} g$ for $10 \mathrm{~min}$. The supernatant was removed, and the amoebae were resuspended in $20 \mathrm{~mL}$ of PAS buffer (Page's amoebic saline) (120 mg NaCl, $4 \mathrm{mg} \mathrm{MgSO}_{4}$ - $7 \mathrm{H}_{2} \mathrm{O}, 4 \mathrm{mg} \mathrm{CaCl} \cdot 2 \mathrm{H}_{2} \mathrm{O}, 142 \mathrm{mg} \mathrm{Na} \mathrm{HPO}_{4}, 136 \mathrm{mg} \mathrm{KH} \mathrm{KH}_{2} \mathrm{PO}_{4}, 1.0$ $\mathrm{L}$ distilled water). The washing procedure was repeated and the amoebae were resuspended in $10 \mathrm{~mL}$ of PAS, at a final concentration of $2.0 \times 10^{5}$ cells $\mathrm{mL}^{-1}$. Aliquots of $1 \mathrm{~mL}$ of this suspension were transferred to 24-well cell culture microplates (Costar, Cambridge, Mass., USA) and allowed to adhere to the wells for $1 \mathrm{~h}$ at $37^{\circ} \mathrm{C}$. Aliquots of $500 \mu \mathrm{L}$ of each prepared sample were added to axenic culture of $A$. castellanii in duplicate. $L$. pneumophila strain ATCC 33155 (Manassas, VA, USA) was used as a positive control at a concentration of approximately $8.0 \times 10^{7} \mathrm{CFU} \mathrm{mL} \mathrm{mL}^{-1}$. The cell suspension $(100 \mu \mathrm{L})$ was added to each well containing amoebae in one $\mathrm{mL}$ of PAS to give a ratio of 40 legionellae per amoebae. After $48 \mathrm{~h}$ at $28^{\circ} \mathrm{C}$, the samples were aspirated and wells were washed once with sterile phosphate buffered saline (PBS) solution, $\mathrm{pH} 7.0$, containing $100 \mu \mathrm{g} \mathrm{mL}^{-1}$ of gentamicin (Sigma, St. Louis, Mo., USA). The mixture was incubated for $2 \mathrm{~h}$ at $37^{\circ} \mathrm{C}$ to kill all extracellular legionellae. The wells were washed with $1 \mathrm{~mL}$ of fresh PBS without gentamicin. After a second period of incubation for $2 \mathrm{~h}$ at $37^{\circ} \mathrm{C}, 100 \mu \mathrm{L}$ of the mixture in each well were spread onto BCYE-GVP, incubated at $37^{\circ} \mathrm{C}$ for five days, and viable intracellular legionellae were determined by colony forming units (CFU) counting.

\section{Isolation of free-living amoebae from water samples}

In order to recover free-living amoebae from the aquatic environmental samples, a portion of water $(500 \mathrm{~mL})$ from each site was filtered through a $1.2 \mu \mathrm{m}$ sterile cellulose ester membrane (Millipore, Ireland). For isolation of amoebae, the membranes were asseptically transferred to soy infusion agar plates, named Foronda's medium (overnight infusion of $2.0 \mathrm{~g}$ soy powder in $1.0 \mathrm{~L}$ of sterile distilled water, paper filtered, and then added of $1.5 \mathrm{~g}$ of agar). The plates were incubated at $25^{\circ} \mathrm{C}$ and examined for the presence and growth of free-living amoebae under an inverted microscope (200X magnification) daily for 7-14 days post-inoculation. Identification of freeliving amoebae was based on characteristics described by Page (37). The size, shape, and number of pseudopodia produced and the character of the movement were noted using a hanging drop preparation.

\section{Isolation of Legionella spp from environmental biofilms}

Biofilms were collected from the surface of oral rinsing cups from dental units, water tank reservoir to cooling tower, evaporative condensers and cold-water tank reservoir, using sterile swabs. These swabs were transported in $5 \mathrm{ml}$ water from the sampling site and inoculated on $\alpha B C Y E$ agar with cysteine and ferric iron. The water used for biofilm transport was centrifuged for $10 \mathrm{~min}$ at $10,000 \mathrm{x}$ g. The pellets were resuspended in $1 \mathrm{ml}$ of sterile distilled water, and an aliquot of $100 \mu \mathrm{L}$ was spread onto $\alpha B C Y E-G V P$ selective agar. For the amoebic coculture procedure, another aliquot of the pellet suspension (200 mL) was spread onto axenic A. castellanii microplates followed by plating onto a selective medium for counting of intracellular bacteria.

\section{Statistical analysis}

The $\chi^{2}$ (chi-square) test was used to evaluate the positivity rate of isolation and identification of the Legionella spp in environmental samples by the proposed methods. The significance of the results was determined by analysis of variance. An overall significance level of 5\% was adopted. All in vitro experiments were carried out in duplicate.

\section{mip gene amplification and sequencing}

Legionella spp strains were submitted to DNA extraction using GFX Genomic Blood DNA Purification kit (Amersham Biosciences, New Jersey, USA), according to the manufacturer's instructions. The genomic DNA was amplified by PCR using mip gene (686-bp nucleotides) primers Legmip-f (27-mer), 5' GGG(AG)ATT(ACG)TTTATGAAGATGA(AG)A(CT)TGG-3' 
and Legmip-r (23-mer), 5'-TC(AG)TT(ATCG)GG(ATG) CC(ATG)AT(ATCG)GG(ATCG)CC(ATG)CC-3' as previously described (43). Each amplification reaction was carried out in total volume of $25 \mu \mathrm{L}$ with the following mixture of components: $1 \mu \mathrm{L}$ of DNA template $\left(50.0 \mathrm{ng} \mu \mathrm{L}^{-1}\right), 1 \times$ reaction buffer, $\mathrm{MgCl}_{2}$ $\left(1.5 \mathrm{mmol} \mathrm{L}^{-1}\right)$, Legmip forward and reverse primers $(1.0 \mu \mathrm{mol}$ $\mathrm{L}^{-1}$ of each primer), deoxynucleosides triphosphate $(200 \mu \mathrm{mol}$ $\mathrm{L}^{-1}$ ), and Platinum Taq DNA polymerase (1.25 units) (Invitrogen Life Technologies, California, USA). Amplification cycles were preceded by denaturation of the samples for 3 minutes at $94^{\circ} \mathrm{C}$, followed by 35 cycles of $60 \mathrm{~s}$ at $94^{\circ} \mathrm{C}, 2 \mathrm{~min}$ at $55^{\circ} \mathrm{C}, 2 \mathrm{~min}$ at $72^{\circ} \mathrm{C}$ and $3 \mathrm{~min}$ to final extension at $72^{\circ} \mathrm{C}$. The amplicons were checked by gel electrophoresis on $1.5 \%$ agarose gels, using 100 bp DNA Ladder (Invitrogen Life Technologies, California, USA) as a molecular marker. The amplicons to be sequenced were purified with the Wizard ${ }^{\circledR}$ PCR Prep DNA Purification System (Promega Corporation, Madison, USA) according to the manufacturer's instructions. Both strands of each amplicon were sequenced with the same primer sets used in the PCR. Sequences were determined with DYEnamic ET Dye Terminator Cycle Sequencing Kit and Thermo Sequenase ${ }^{\mathrm{TM}}$ II DNA Polymerase (Amersham Biosciences, Buckinghamshire, UK), according to the MegaBACE 1000 protocol (Amersham Biosciences, Piscataway, NJ). Lane tracking and base calling was done with Cimarron 3.12 software (Amersham Biosciences, Piscataway, NJ).

\section{Phylogenetic analyses}

Nucleotide sequences obtained with the forward and reverse primers were combined and aligned manually using BioEdit Sequence Alignment Editor version 5.0.9 (22). The consensus sequences were compared with mip gene sequences provided by GenBank database using the BLAST software (1) at the National Center for Biotechnology Information (NCBI). Multiple alignments were accomplished with nucleotide and aminoacid sequences using the multiple alignments Clustal W software (49). Phylogenetic and molecular evolutionary analyses were conducted using MEGA3 (Molecular Evolutionary Genetic Analysis software version 3.1) (30). Phylogenetic tree of Legionella isolates were constructed by the neighbor-joining (NJ) method without gaps and pairwise distances were calculated using the maximum likelihood option. The Modeltest version 3.06 programs (43) was used to find the best model of evolution that fit the data, and the Tamura-Nei model of evolution (48) was used for NJ analyses. Bootstrap analysis was used to estimate the reliability of nodes. Multiple data sets were used $(n=1,000)$, and a number of dendrograms were compared.

\section{Nucleotide sequence numbers}

All mip gene sequences obtained from environmental strains were deposited in GenBank under accession numbers AY849371, and AY974251 to AY974258. The accession numbers in the
GenBank of NCBI for the sequences used for comparison in this study are as follows: L. gormanii (U91638) and $L$. pneumophila (AF022334, S42595, AJ496265, AF095220, AF095219, AF095225, AE017354, AF095215, AF095223, AJ496271, AF022326).

\section{RESULTS}

Table 1 shows the detection of L. pneumophila according to the source of the samples (natural reservoirs and man-made systems) and the detection method. Results showed that Legionellae were detected in all environments in the metropolitan region of Sao Paulo city, Brazil. The results for the presence of L. pneumophila and non-pneumophila species according to the detection method are detailed below.

\section{Direct fluorescent antibody (DFA) staining}

L. pneumophila was detected in seven water samples coming from four different sources: cooling tower (one sample), water tank reservoir to cooling tower (only in the water sample), boiler (one sample) and shower heads (four samples). All of them were also isolated by culturing onto a selective medium $\alpha B C Y E-G V P$ carried out in parallel.

\section{Direct culture on selective medium}

The direct plate culture procedure of water samples using the $\alpha B C Y E-G V P$ agar selective medium showed the best results in the detection of legionellae. Nine strains isolated from the water samples were identified as L. pneumophila by DFA staining and slide agglutination test. The overgrowth of fastergrowing bacteria and fungi was minimized with the heat treatment of samples, improving the isolation of suspect colonies to distinguish legionellae from non-legionellae. The nine Legionella strains were isolated from four sources as follows: cooling towers (one isolate: strain BR-09), water tank reservatory to cooling tower (two isolates, being one isolate from water sample: strain BR-07, and one from biofilm sample: strain BR-08), boiler (one isolate: strain BR-10) and shower heads (five isolates: strains BR-02, BR-03, BR-04 and BR-05).

\section{Amoebic coculture procedure}

Amoebic coculture with Acanthamoeba castelanii (strain ATCC 30011) was applied to improve the isolation of Legionella spp. However, eight strains were isolated when amoebic coculture procedure was applied as a first step before plate culture, in contrast to nine strains isolated by direct culturing (Table 1). However, all strains obtained by direct inoculation onto selective medium showed a lower amount of viable cells in comparison to amoebic coculture procedure (data not shown). In addition, free-living amoebae, i.e. Acanthamoeba sp, Hartmanella vermiformis and Vahlkampfia sp, were isolated in all screened samples. 
Table 1. Legionella pneumophila detection according to the source of the sample and detection method.

\begin{tabular}{|c|c|c|c|c|c|}
\hline \multirow[t]{2}{*}{ Source of samples } & \multirow{2}{*}{$\begin{array}{l}\text { Number of } \\
\text { samples } \\
\text { collected }\end{array}$} & \multirow{2}{*}{$\begin{array}{c}\text { Number of } \\
\text { samples positive to } \\
\text { L. pneumophila }\end{array}$} & \multicolumn{3}{|c|}{$\begin{array}{l}\text { Number of positive samples according to } \\
\text { the detection method*** }\end{array}$} \\
\hline & & & $\begin{array}{l}\text { Direct Fluorescent } \\
\text { Antibody }\end{array}$ & $\begin{array}{l}\text { Plate culture on } \\
\text { selective medium }\end{array}$ & $\begin{array}{l}\text { Amoebic coculture } \\
\text { procedure }\end{array}$ \\
\hline Natural water reservoir & 4 & 0 & 0 & 0 & 0 \\
\hline Dental units* & 10 & 0 & 0 & 0 & 0 \\
\hline Cooling towers & 13 & 1 & 1 & 1 & 1 \\
\hline $\begin{array}{l}\text { Water tank reservatory } \\
\text { to cooling tower* }\end{array}$ & 2 & 2 & $1 * *$ & 2 & 2 \\
\hline Boiler & 1 & 1 & 1 & 1 & 1 \\
\hline Evaporative condensers* & 4 & 0 & 0 & 0 & 0 \\
\hline Cold water tank reservoir* & 2 & 0 & 0 & 0 & 0 \\
\hline Shower heads & 31 & 5 & 4 & 5 & 4 \\
\hline Total of samples & 67 & 9 & 7 & 9 & 8 \\
\hline
\end{tabular}

*Water and biofilm samples were collected; ** Positive only in water sample; *** $\chi^{2}$ (chi-square) test indicated that the statistical difference among detection methods was not significant $(\mathrm{P}>0.05)$.

Molecular identification of Legionella environmental isolates

PCR and sequence analysis applied to the Legionella isolates resulted in amplicon sequences containing approximately 686 base pairs. Sequenced length of the mip gene ranged between $661 \mathrm{bp}$ and $715 \mathrm{bp}$. Overall mip gene sequence similarity values of some $L$. pneumophila strains retrieved from GenBank database and all the L. pneumophila isolated from environmental samples ranged between 98.6 and $100 \%$. Phylogenetic tree inferred from the mip gene sequences indicated that the nine isolates were grouped into three distinct clusters (Fig. 1). Legionella strains BR-05 to BR-10 showed $100 \%$ of similarity with $L$. pneumophila serogroup 1 , while cluster 2 showed an association between Legionella strain BR03 (isolated from a water sample of industrial shower) and $L$. pneumophila serogroup 8 (strain CDC F920). Finally, cluster 3 was constructed by two others $L$. pneumophila isolated from industrial shower (strains BR-02 and BR-04) and L. pneumophila serogroups 6,8 and 12 .

\section{Statistical analysis}

When $\chi^{2}$ values were calculated, the differences in the frequency of isolation of L. pneumophila among the methods used in this research were not significant $(\mathrm{P}>0.05)$. All three methods may be used to isolate and identify Legionella spp with $95 \%$ of reproducibility level.

\section{DISCUSSION}

Legionella species have been isolated from a wide variety of water types, such as potable water of hospitals (6), industries and hotels (19), ground and surface water and biofilms (14). Moreover, several authors have described the isolation of Legionella spp from showers, cooling towers and boilers $(26,33,52)$, which is in agreement with the findings of the present study. In contrast with previous findings reported in literature $(4,51)$, Legionella spp were not detected in dental units water. One possible explanation for negative results to legionellae detection in dental units could be the presence of a large number of heterotrophic bacteria in those samples, which could secrete bacteriocins that inhibit the growth of Legionella species (53).

In this study, nine isolated strains were identified as $L$. pneumophila by direct plating, fluorescent antibody test and sequencing of mip gene. The use of the $\alpha B C Y E-G V P$ selective medium in the isolation of Legionella spp from environmental samples was more sensitive than the amoebic coculture procedure. The results were consistent with previous observations (5), and indicated that Legionella pneumophila strains could be isolated either as intracellular pathogens of protozoan or as microbial plankton. Moreover, the presence of L. pneumophila in water and biofilm samples from the same cooling tower confirmed that this bacterium colonized distinct environments at the same site. This is an important aspect in the disinfection process on man-made systems.

Fliermans et al. (17) observed that Legionella pneumophila was part of the natural aquatic environment and that this bacterium was capable to survive at extreme environmental conditions. However, in the present study, Legionella spp was not detected from the freshwater samples from natural reservoirs, regardless the isolation and identification methods. Several biotic and abiotic factors may explain the unsuccessful detection 


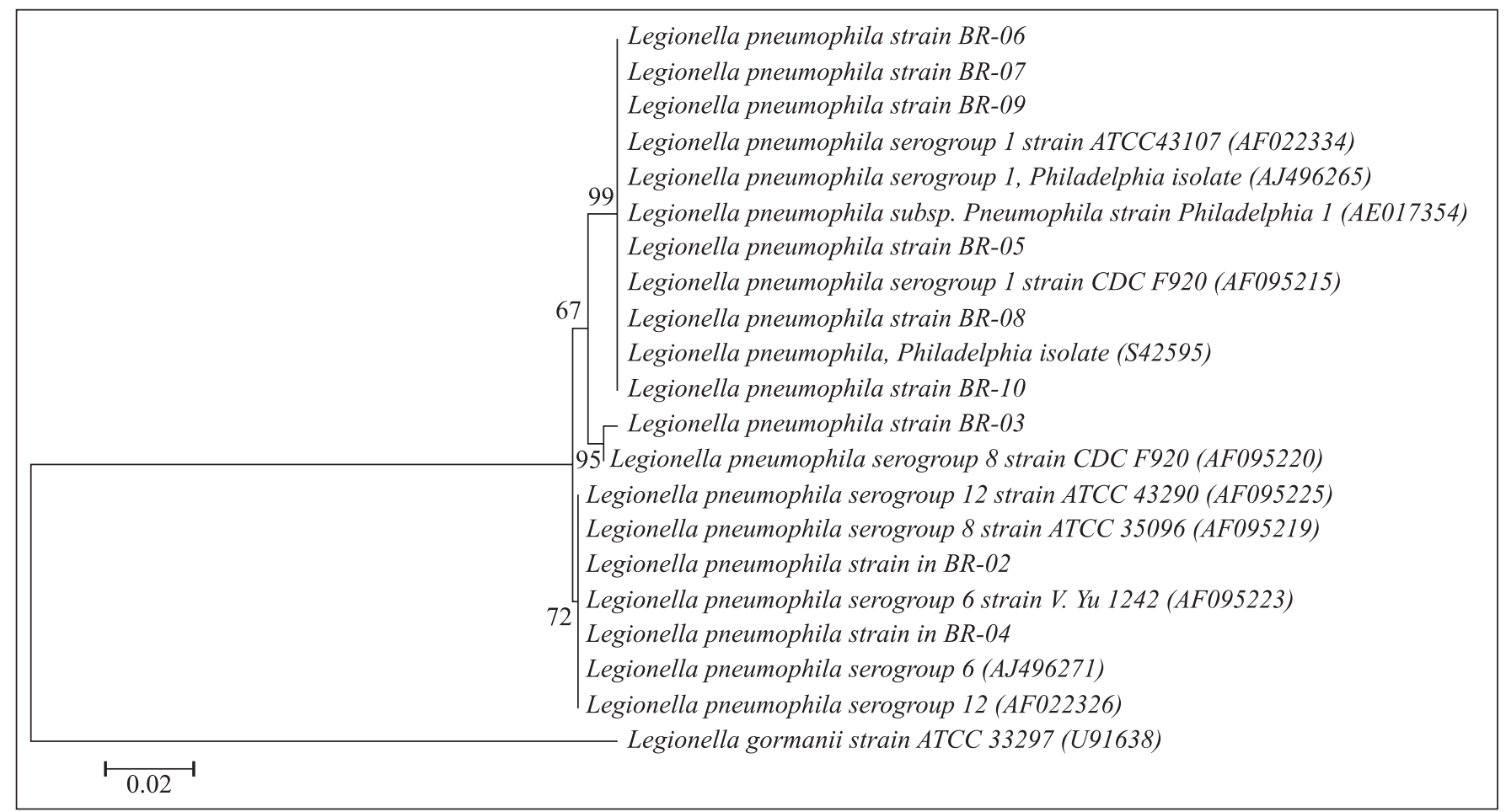

Figure 1. Consensus Phylogenetic tree showing distances based on the mip gene sequences (599 bp) among 09 isolates (labeled as L. pneumophila strain BR) from cooling towers (BR-09), water tank reservatory to cooling tower (BR-07 isolated from water and BR-08 isolated from biofilm samples), and shower heads (BR-02, BR-03, BR-04, BR-05) sampled. mip gene nucleotide sequences from environmental isolates were compared with reference strains obtained from GenBank (accession numbers in parentheses). The species L. gormanii (ATCC 33297) was used as outgroup. Dendrogram was generated by using MEGA software packages version 3.0. Bootstrap analysis was applied to the data, and the values greater than $50 \%$ ( $\mathrm{n}=1,000$ replications) are indicated at the nodes. The ratio of substitution per 100 nucleotides in dendrogram was 0.02 as demonstrated in scale bar.

of legionellae in those environments: the presence of viable but non-culturable cells, loss of viability of bacteria after collection, presence of faster-growing bacteria as potential biological competitors, and low concentration of legionellae in the samples. Similar observations were reported by other authors $(8,25,40)$. According to Lee and West (32), legionellae are usually a minor component of a bacterial population in freshwater and moist natural environments, and the prime factor affecting their incidence appears to be water temperature. Legionellae appear to have a predilection for the warm water encountered in artificial environments, such as man-made systems.

Looking for better recovery results, Sanden et al. (45) observed that preincubation of water samples with free-living amoebae for several days increased the recovery of Legionella spp, which was related with proliferation of amoebae in the samples. The same observations were done by Bartie et al. (5), who showed that re-incubation of water samples concentrates with autochthonous amoebae improved the culturability of legionellae in a selective medium.
Results of amplification and sequencing of mip gene carried out in this study are in accordance to several authors $(30,44,54)$. The mip gene encodes a 24-kDa surface protein (Mip) and has been chosen as genetic marker because it plays a crucial role in the resistance of $L$. pneumophila to intracellular killing (10). Results of PCR and sequencing procedures revealed that Legionella pneumophila was the only species in the sampled aquatic environments. The phylogenetic inference of mip gene sequences showed three different serogroup clusters related to L. pneumophila isolates from man-made systems, suggesting that these isolates are well adapted to environmental survival. These data are in accordance with previous reports in others regions around the world, where limited genetic variability of environmental isolates of $L$. pneumophila in the water systems and the prevalence of one genotype of this bacterium in a large proportion of man-made aquatic environments were reported (7,11,12,24,34,47). Although Legionella species other than $L$. pneumophila may occur in man-made systems, one explanation for the apparent spread of $L$. pneumophila observed in this 
study could be the symbiotic interaction between this bacterium and free-living amoebae. It is known that amoebae are natural hosts of legionellae and play a major role in the multiplication of L. pneumophila in some water cultures $(2,3,16,29,46)$. In addition, amoebae were found in the water samples of all eight sources sampled in the study. It is also possible that Legionella nonpneumophila species are less pathogenic than L. pneumophila due to lower infectivity or a poor intracellular growth, which could explain the major occurrence of virulent L. pneumophila strains in those environmental sources.

In regard to the detection procedures used in this study, no statistical significant differences were observed among them, indicating that the plate culture method, the coculture with freeliving amoebae and the direct fluorescent assay are equally effective tools to monitor Legionella population on man-made aquatic environments. In addition, results of PCR and sequencing reactions of mip gene, applied in this study as a "virulence factor" gene, provided genetic evidence for the occurrence of virulent Legionella pneumophila strains in manmade systems which could infect both protozoan and mammalian phagocytic cells. Finally, the close clonal nature of $L$. pneumophila obtained in this study suggests that the potential sources of legionellae contamination could be the distribution system responsible for the water supply of the man-made systems or other disseminators that draw upon a public water supply.

\section{ACKNOWLEDGEMENTS}

The authors wish to acknowledge G. S. Bellicanta, R. C. Gamba and M. C. Daulisio for technical assistance in molecular biology and immunofluorescence microscopy, Dr. W. Francisco for supplying the Legionella reference strains used in this study and Conselho Nacional de Desenvolvimento Científico e Tecnológico (CNPq) for financial support.

\section{RESUMO}

\section{Detecção de Legionella pneumophila por métodos de cultivo e moleculares em sistemas artificiais de climatização de ambientes interiores em São Paulo - Brasil}

Legionella pneumophila é uma bactéria patogênica associada à habitats aquáticos de ambientes naturais e artificiais. Casos clínicos de legionelose têm sido descritos no Brasil, mas a incidência e concentração desta bactéria em fontes ambientais ainda são pouco conhecidas. Assim, o presente estudo foi desenvolvido para avaliar a ocorrência de bactérias do gênero Legionella na cidade de São Paulo, Brasil, utilizando diferentes métodos de isolamento e identificação. Sessenta e sete amostras de água e biofilme de reservatórios naturais e sistemas artificiais de climatização de ambientes interiores foram coletadas e analisadas quanto à presença de Legionella spp por métodos de cultivo em meio-de-cultura seletivo, cocultivo com amebas de vida livre axênicas e ensaios de imunofluorescência direta (IFD). Os resultados demonstraram que bactérias do gênero Legionella não foram detectadas em reservatórios naturais de água, Legionella pneumophila foi isolada de sistemas artificiais de climatização, com predominância de cepas de Legionella pneumophila sorogrupo 1. Apesar de não ter havido diferença estatística significante entre os métodos de detecção propostos, o método de cultivo em placa produziu o melhor resultado quanto ao número de amostras positivas para L. pneumophila, seguido do procedimento de cocultivo com amebas e ensaio de imunofluorescência direta. Os resultados das reações de PCR e sequenciamento revelaram que a aplicação do gene potencializador de infecção em macrófagos como marcador molecular foi um importante implemento na identificação de isolados ambientais de $L$. pneumophila. A concordância existente entre os três métodos de detecção - quando todos os métodos produziram resultados similares - e a prevalência de uma espécie de Legionella nos sistemas artificiais amostrados poderia sugerir que a ocorrência desta bactéria tenha sido influenciada pela maior concentração de íons metálicos dissociados na água daqueles sistemas do que nos reservatórios naturais. Assim, os resultados deste estudo revelaram que a água proveniente dos sistemas artificiais de climatização de ambientes interiores pode servir como reservatório de L. pneumophila e outros microrganismos, incluindo protozoários de vida livre.

Palavras-chave: Legionella pneumophila, amebas de vida livre, sistemas artificiais de climatização

\section{REFERENCES}

1. Altschul, S.F.; Madden, T.L.; Schäffer, A.A.; Zhang, J.; Zhang, Z.; Miller, W.; Lipman, D.J. (1997). Gapped BLAST and PSI-BLAST: a new generation of protein database search programs. Nucleic Acid Res., 25(17), 3389-3402.

2. Atlas, R.M. (1999). Legionella: from environmental habitats to disease pathology, detection and control. Environ. Microbiol., 1(4), 283-293.

3. Barbaree, J.M.; Fields, B.S.; Feeley, J.C.; Gorman, G.W.; Martin, W.T. (1986). Isolation of protozoa from water associated with a legionellosis outbreak and demonstration of intracellular multiplication of Legionella pneumophila. Appl. Environ. Microbiol., 51(2), 422-424.

4. Barbeau, J.; Buhler, T. (2001). Biofilms augment the number of freeliving amoebae in dental unit waterlines. Res. Microbiol., 152(8), 753-760.

5. Bartie, C.; Venter, S.N.; Nel, L.H. (2003). Identification methods for Legionella from environmental samples. Water Res., 37(6), 1362 1370 .

6. Bernander, S.; Jacobson, K.; Helbig, J.H.; Luck, P.C.; Lundholm, M. (2003). A hospital-associated outbreak of Legionnaires' disease caused by Legionella pneumophila serogroup 1 is characterized by stable 
genetic fingerprinting but variable monoclonal antibody patterns. $J$. Clin. Microbiol., 41(6), 2503-2508.

7. Bezanson, G.; Burbridge, S.; Haldane, D.; Yoell, C.; Marrie, T. (1992). Diverse populations of Legionella pneumophila present in the water of geographically clustered institutions served by the same reservoir. J. Clin. Microbiol., 30(3), 570-576.

8. Catalan, V.; Moreno, C.; Dasi, M.A.; Muñoz, C.; Apraiz, D. (1994). Nested polymerase chain reaction for detection of Legionella pneumophila in water. Res. Microbiol., 145(8), 603-610.

9. Chedid, M.B.F.; Ilha, D.O.; Chedid, M.F.; Dalcin, P.R.; Buzzetti, M.; Saraiva, P.J.; Griza, D.; Barreto, S.S.M. (2005). Community-acquired pneumonia by Legionella pneumophila serogroups 1-6 in Brazil. Resp. Med., 99(8), 966-975.

10. Cianciotto, N.P.; Bangsborg, J.M.; Eisenstein, B.I.; Engleberg, N.C. (1990). Identification of mip-like genes in the genus Legionella. Infect. Immun., 58(9), 2912-2918.

11. Darelid, J.; Bernander, S.; Jacobson, K.; Löfgren, S. (2004). The presence of a specific genotype of Legionella pneumophila serogroup 1 in a hospital and municipal water distribution system over a 12year period. Scan. J. Infect. Dis., 36(6-7), 417-423.

12. Doleans, A.; Aurell, H.; Reyrolle, M.; Lina, G.; Freney, J.; Vandenesch, F.; Etienne, J.; Jarraud, S. (2004). Clinical and environmental distributions of Legionella strains in France are different. J. Clin. Microbiol., 42(1), 458-460.

13. Edelstein, P.H. (1981). Improved semiselective medium for isolation of Legionella pneumophila from contaminated clinical and environmental specimens. J. Clin. Microbiol., 14(3), 298-303.

14. Emtiazi, F.; Schwartz, T.; Marten, S.M.; Krolla-Sidenstein, P.; Obst, U. (2004). Investigation of natural biofilms formed during the production of drinking water from surface water embankment filtration. Water Res., 38(5), 1197-1206.

15. Fields, B.S. (1996). The molecular ecology of legionellae. Trends Microbiol., 4(7), 286-290.

16. Fields, B.S.; Benson, R.F.; Besser, R.E. (2002). Legionella and Legionnaires' disease: 25 years of investigation. Clin. Microbiol. Rev., 15(3), 506-526.

17. Fliermans, C.B.; Cherry, W.B.; Orrison, L.H.; Smith, S.J.; Tison, D.L.; Hope, D.H. (1981). Ecological distribution of Legionella pneumophila. Appl. Environ. Microbiol., 41(1), 9-16.

18. Fliermans, C.B.; Cherry, W.B.; Orrison, L.H.; Thacker, L. (1979). Isolation of Legionella pneumophila from nonepidemic-related aquatic habitats. Appl. Environ. Microbiol., 37(6), 1239-1242.

19. Fry, A.M.; Rutman, M.; Allan, T.; Scaife, H.; Salehi, E.; Benson, R.; Fields, B.; Nowicki, S.; Parrish, M.K.; Carpenter, J.; Brown, E.; Lucas, C.; Horgan, T.; Koch, E.; Besser, R.E. (2003). Legionnaires' disease outbreak in an automobile engine manufacturing plant. $J$. Infect. Dis., 187(6), 1015-1018.

20. Fry, N.K.; Warwick, S.; Saunders, N.A.; Embley, T.M. (1991). The use of $16 \mathrm{~S}$ ribosomal RNA analyses to investigate the phylogeny of the family Legionellaceae. J. Gen. Microbiol., 137(5), 1215-1222.

21. Grattard, F.; Ginevra, C.; Riffard, S.; Ros, A.; Jarraud, S.; Etienne, J.; Pozzetto, B. (2006). Analysis of the genetic diversity of Legionella by sequencing the $23 \mathrm{~S}-5 \mathrm{~S}$ ribosomal intergenic spacer region: from phylogeny to direct identification of isolates at the species level from clinical specimens. Microb. Infect., 8(1), 73-83.

22. Hall, T.A. (1999). BioEdit: a user-friendly biological sequence alignment editor and analysis program for Windows 95/98/NT. Nucl. Acids Symp. Ser. 41, 95-98.

23. Helbig, J.H.; Lück, P.C.; Kunz, B.; Bubert, A. (2006). Evaluation of the duopath Legionella lateral flow assay for identification of Legionella pneumophila and Legionella species culture isolates. Appl. Environ. Microbiol., 72(6), 4489-4491.

24. Huang, B.; Heron, B.A.; Gray, B.R.; Eglezos, S.; Bates, J.R.; Savill, J. (2004). A predominant and virulent Legionella pneumophila serogroup 1 strain detected in isolates from patients and water in
Queensland, Australia, by an amplified fragment length polymorphism protocol and virulence gene-based PCR assays. J. Clin. Microbiol., 42(9), 4164-4168.

25. Hussong, D.; Colwell, R.R.; O' Obrien, M.; Weiss, E.; Pearson, A.D.; Wiever, R.M.; Burge, W.D. (1987). Viable Legionella pneumophila not detectable by culture on agar media. Bio/Technol., 5, 947-950.

26. Kim, B.R.; Anderson, J.E.; Mueller, S.A.; Gaines, W.A.; Kendall, A.M. (2002). Literature review - efficacy of various disinfectants against Legionella in water systems. Water Res., 36(18), 44334444.

27. Ko, K.S.; Lee, H.K.; Park, M.Y.; Lee, K.H.; Yun, Y.J.; Woo, S.Y.; Miyamoto, H.; Kook, Y.H. (2002a). Application of RNA polymerase beta-subunit gene (rpoB) sequences for the molecular differentiation of Legionella species. J. Clin. Microbiol., 40(7), 2653-2658.

28. Ko, K.S.; Lee, H.K.; Park, M.Y.; Park, M.S.; Lee, K.H.; Woo, S.Y.; Yun, Y.J.; Kook, Y.H. (2002b). Population genetic structure of Legionella pneumophila inferred from RNA polymerase gene (rpoB) and DotA gene (dotA) sequences. J. Bacteriol., 184(8), 2123-2130.

29. Kuiper, M.W.; Wullings, B.A.; Akkermans, A.D.; Beumer, R.R.; van der Kooij, D. (2004). Intracellular proliferation of Legionella pneumophila in Hartmanella vermiformis in aquatic biofilms grown on plasticized polyvinyl chloride. Appl. Environ. Microbiol., 70(11), 6826-6833.

30. Kumar, S.; Tamura, K.; Nei, M. (2004). MEGA3: Integrated software for Molecular Evolutionary Genetics Analysis and sequence alignment. Brief. Bioinf., 5(2), 150-163.

31. La Scola, B.; Birtles, R.J.; Greub, G.; Harrison, T.J.; Ratcliff, R.M.; Raoult, D. (2004). Legionella drancourtii sp. nov., a strictly intracellular amoebal pathogen. Int. J. Syst. Evol. Microbiol., 54(pt 3), 699-703.

32. Lee, J.V.; West, A.A. (1991). Survival and growth of Legionella species in the environment. J. Appl. Bacteriol., 70, 121S-129S.

33. Leoni, E.; Legnani, P.P.; Bucci Sabattini, M.A.; Righi, F. (2001). Prevalence of Legionella spp in swimming pool environment. Water Res., 35(15), 3749-3753.

34. Lepeuple, A.S.; Jovic, M.; de Roubin, M.R. (2004). Molecular typing of the Legionella pneumophila population isolated from several locations in a contaminated water network. Water Sci. Technol., 50(1), 281-285.

35. Levin, A.S.; Caiaffa Filho, H.H.; Sinto, S.I.; Sabbaga, E.; Barone, A.A.; Mendes, C.M. (1991). An outbreak of nosocomial Legionnaires' disease in a renal transplant unit in Sao Paulo, Brazil. Legionellosis Study Team. J. Hosp. Infect., 18(3), 243-248.

36. Mampel, J.; Spirig, T.; Weber, S.S.; Haagensen, J.A.J.; Molin, S.; Hilbi, H. (2006). Planktonic replication is essential for biofilm formation by Legionella pneumophila in a complex medium under static and dynamic flow conditions. Appl. Environ. Microbiol., 72(4), 2885-2895.

37. Page, F.C. (1988). A new key to freshwater and soil Gymnamoeba. Freshwater Biological Association, Ambelside, United Kingdom.

38. Park, M.; Yun, S.T.; Kim, M.S.; Chun, J.; Ahn, T.I. (2004). Phylogenetic characterization of Legionella-like endosymbiotic Xbacteria in Amoeba proteus: a proposal for 'Candidatus Legionella jeonii' sp. nov. Environ. Microbiol., 6(12), 1252-1263.

39. Park, M.Y.; Ko, K.S.; Lee, H.K.; Park, M.S.; Kook, Y.H. (2003). Legionella busanensis sp. nov., isolated from cooling tower water in Korea. Int. J. Syst. Evol. Microbiol., 53(pt 1), 77-80.

40. Payment, P.; Bérubé, A.; Perreault, D.; Armon, R.; Trubel, M. (1989). Concentration of Giardia lamblia cysts, Legionella pneumophila, Clostridium perfringens, human enteric viruses, and coliphages from large volumes of drinking water, using a single filtration. Can. J. Microbiol., 35(10), 932-935.

41. Pellizari, V.H.; Martins, M.T. (1995). Occurrence of Legionella sp in water samples from man-made systems of Sao Paulo - Brazil. Rev. Microbiol., 26(3), 186-191. 
42. Pereira Gomes, J.C.; Mazieri, N.A.; de Godoy, C.V.; Rocha Ados, S. (1990). Legionella pneumophila associated with acute respiratory insufficiency: 1st isolation in Brazil. Rev. Inst. Med. Trop. Sao Paulo, 31(6), 368-376.

43. Posada, D.; Crandall, K.A. (1998). Modeltest: Testing the model of DNA substitution. Bioinformatics, 14(9), 817-818.

44. Ratcliff, R.M.; Lanser, J.A.; Manning, P.A.; Heuzenroeder, M.W. (1998). Sequence-based classification scheme for the genus Legionella targeting the mip gene. J. Clin. Microbiol., 36(6), 15601567.

45. Samrakandi, M.M.; Cirillo, S.T.G.; Ridenour, D.A.; Bermudez, L.E.; Cirillo, J.D. (2002). Genetic and phenotypic differences between Legionella pneumophila strains. J. Clin. Microbiol., 40(4), 13521362 .

46. Sanden, G.N.; Morril, W.E.; Fields, B.S.; Breiman, R.F.; Barbaree, J.M. (1992). Incubation of water samples containing amoebae improves detection of legionellae by the culture method. Appl. Environ. Microbiol., 58(6), 2001-2004.

47. Scaturro, M.; Losardo, M.; De Ponte, G.; Ricci, M.L. (2005) Comparison of three molecular methods used for subtyping of Legionella pneumophila strains isolated during an epidemic of legionellosis in Rome. J. Clin. Microbiol., 43(10), 5348-5350.
48. Tamura, K.; Nei, M. (1993). Estimation of the number of nucleotide substitutions in the control region of mitochondrial DNA in human and chimpanzees. Mol. Biol. Evol., 10(3), 512-526.

49. Thompson, J.D.; Higgins, D.G.; Gibson, T.J. (1994). CLUSTAL W: improving the sensitivity of progressive multiple sequence alignment through sequence weighting, position-specific gap penalties and weight matrix choice. Nucleic Acids Res., 22(22), 4673-4680.

50. Wadowsky, R.M.; Yee, R.B. (1981). Glycine-containing selective medium for isolation of Legionellaceae from environmental specimens. Appl. Environ. Microbiol., 42(5),768-772

51. Walker, J.T.; Bradshaw, D.J.; Bennett, A.M.; Fulford, M.R.; Martin, M.V.; Marsh, P.D. (2000). Microbial biofilm formation and contamination of dental-unit water systems in general dental practice. Appl. Environ. Microbiol., 66(8), 3363-3367.

52. Wellinghausen, N.; Forst, C.; Marre, R. (2001). Detection of legionellae in hospital water samples by quantitative real-time LightCycler PCR. Appl. Environ. Microbiol., 67(9), 3985-3993.

53. Williams, H.N.; Paszko-Kolva, C.; Shahamat, M.; Palmer, C.; Pettis, C.; Kelley, J. (1996) Molecular techniques reveal high prevalence of Legionella in dental units. J. Am. Dent. Assoc., 127(8), 1188-1193.

54. Wilson, D.A.; Yen-Lieberman, B.; Reischl, U.; Gordon, S.M.; Procop, G.W. (2003). Detection of Legionella pneumophila by real-time PCR for the mip gene. J. Clin. Microbiol., 41(7), 3327-3330. 